\title{
Quantitative Enzyme Histochemistry of Steroid and Glucuronide Synthesis in Testes and Seminal Vesicle, and its Correlation to Plasma Gonadotropin Level in Clarias gariepinus
}

\author{
J.W. RESINK, R. VAN DEN HURK* , P.K. VOORTHUIS, M. TERLOU, R. DE LEEUW and \\ W.J.A.R. VIVEEN ${ }^{1}$ \\ Department of Experimental Zoology, Research Group for Comparative Endocrinology, \\ University of Utrecht, P.O. Box 80.058, 3508 TB Utrecht (The Netherlands) \\ ${ }^{2}$ Department of Fish Culture and Fisheries, Agricultural University, P.O. Box 338,6700 AH \\ Wageningen (The Netherlands)
}

(Accepted 8 December 1986)

\section{ABSTRACT}

Resink, J.W., Van Den Hurk, R., Voorthuis, P.K., Terlou, M., De Leeuw, R. and Viveen, W.J.A.R., 1987. Quantitative enzyme histochemistry of steroid and glucuronide synthesis in testes and seminal vesicle, and its correlation to plasma gonadotropin level in Clarias gariepinus. Aquaculture, 63: 97-114.

In spawning Clarias gariepinus from the Hula Nature Reserve in Northern Israel, the mean value for the seminal vesicle somatic index (SVSI) had decreased as compared with that in prespawning fish, due to loss of seminal vesicle fluid. Mean gonadosomatic index (GSI), however, had increased, probably as a result of hydration, $3 \alpha$-Hydroxysteroid dehydrogenase ( $3 \alpha \mathrm{HSD}$ ), $3 \beta \mathrm{HSD}$ and uridine diphosphoglucose dehydrogenase (UDPGD) reactions were demonstrated in interstitial cells of both testis and seminal vesicle. UDPGD reactions were also found in the epithelium of the seminal vesicle tubules. Quantitative determination of the enzyme reactions with a computerized image analysis system revealed that total activity of all three enzymes in interstitial cells of the seminal vesicle was distinctly stronger in spawning fish. Prespawning and spawning fish did not differ in total UDPGD activity in the epithelium lining the seminal vesicle tubules. In the testes of spawning fish, total 38HSD activity was stronger and total UDPGD activity weaker than in prespawning fish, but total $3 \alpha$ HSD activity was not different. Plasma gonadotropin (GTH) levels in male catfish were low as compared with females. This level was significantly increased in spawning males and extremely high in ovulated female spawning fish. The findings point to marked changes in the production of steroids and glucuronides in the reproductive organ system during spawning, especially in the seminal vesicle. These changes are accompanied by elevated levels of circulating GTH.

*To whom correspondence should be addressed. 


\section{INTRODUCTION}

Under natural conditions mass spawning of the African catfish, Clarias gariepinus, taken place in shallow inundated vegetated areas. According to Micha (1973, 1975), Van Der Waal (1974), Richter (1976) and Bruton (1979), rainfall and the inflow of water are cues for the spawning process. The interval between external stimulation and readiness to spawn is short $(8-36 \mathrm{~h})$. This requires a good synchronization of sexual activities. As spawning takes place in turbid water and mostly during the night, chemical communication by pheromones is likely to play a major role. In various teleosts, intraspecific chemical stimuli are involved in different steps of spawning process (for reviews, see Colombo et al., 1982; Liley, 1982; Liley and Stacey, 1983; Stacey et al., 1986). Data about the nature of these pheromones are scarce. Recently, steroid glucuronides produced in fish gonads have been demonstrated to serve as sex attractants for ovulated female Gobius jozo (Colombo et al., 1980, 1982) and male zebrafish, Brachydanio rerio (Van Den Hurk and Lambert, 1983). In zebrafish it has also been shown that water-soluble substances from the male induce ovulation in females (Chen and Martinich, 1975). These latter substances are probably steroid glucuronides (Lambert et al., 1986; Van Den Hurk et al., 1987c). Likewise, steroid glucuronides from male African catfish might elicit reproductive behaviour and spawning.

In male Clarias gariepinus both testes (Schoonen and Lambert, 1986a) and seminal vesicles (Schoonen and Lambert, 1986b) are able to synthesize steroid glucuronides. This has been confirmed by enzyme histochemical studies (Van Den Hurk et al., 1987a,b). Recent gas chromatography-mass spectrometry analysis of the seminal vesicle fluid showed the presence of different steroid glucuronides (Schoonen et al., 1987). Secretion of the seminal vesicle fluid takes place via the sperm duct (Van Den Hurk et al., 1987b). In this way, steroid glucuronides might reach the water and then function as pheromones, perhaps via a stimulation of gonadotropin release in female conspecifics.

The present paper deals with a quantitative enzyme-histochemical study of testes and seminal vesicles of catfish from a natural habitat to determine the capacity to form steroid glucuronides during the spawning period. Histometrical studies of seminal vesicles furthermore were carried out to estimate changes in the amount of seminal vesicle fluid. The gonadosomatic index and the seminal vesicle somatic index were established as a basis for this study. In addition, plasma gonadotropin levels were measured in male and female catfish by means of a radioimmunoassay, to investigate a possible endogenous surge during natural spawning. In females, the presence or absence of mature oocytes and ovulated eggs were verified. 
MATERIALS AND METHODS

Animals

Mature African catfish, Clarias gariepinus (ca. $2 \mathrm{~kg}$ ), were collected with a gill net in the Hula Nature Reserve in Northern Israel. Prespawning fish were caught on 26 June. At that time the water level was low and the spawning site dried-up. Water temperature was $29^{\circ} \mathrm{C}$. During the following days the water level rose after the inflow of water from a nearby pool. Spawning fish were collected on 1 July, i.e. two days after flooding of the spawning site. These spawning fish showed reproductive behaviour, such as males following females and folding of the male around the head of the female, as previously described by Van Der Waal (1974) and Bruton (1979). The spawning site consisted of shallow water with aquatic plants and flooded terrestrial vegetation. The water temperature was $27^{\circ} \mathrm{C}$.

All animals were caught between 09.00 and $12.00 \mathrm{~h}$ and transported to the laboratory. They were then anaesthetized with $0.1 \% 2$-phenoxy-ethanol and weighed. Blood samples were taken by puncturing the caudal vasculature, using heparinized syringes. After centrifugation $\left(10 \mathrm{~min}\right.$ at $\left.800 \mathrm{~g}, 4^{\circ} \mathrm{C}\right)$ the plasma was stored at $-20^{\circ} \mathrm{C}$ until GTH measurement.

For female catfish, ovulation was checked by the release of oocytes from the ovipore, following slight pressure on the abdomen. Samples of oocytes from unovulated fish were aspirated through a cannula. The diameter of these oocytes was measured. Thereafter, they were fixed in ethanol $(96 \%)$-formol (35\%)-acetic acid (6:3:1) and then microscopically checked for germinal vesicle migration and breakdown, i.e. final maturation. Female fish with oocytes having a diameter larger than $1 \mathrm{~mm}$ are considered to have completed vitellogenesis and to be at the postvitellogenic stage (Richter and Van Den Hurk, 1982).

From male fish, the testes and the seminal vesicle were dissected and weighed to determine the gonadosomatic index (GSI) and seminal vesicle somatic index (SVSI), i.e. GSI $=($ testes weight/body weight $) \times 100 ;$ SVSI $=($ seminal vesicle weight/body weight) $\times 100$.

\section{Histology and enzyme histochemistry}

From each fish, mid-parts of a testis and proximal and distal parts of the seminal vesicle lobes were used. Testicular tissue was fixed in Bouin-Hollande and seminal vesicle tissue in formol-calcium for histological studies. After dehydration, the fixed material was embedded in paraffin and sectioned at 5 $\mu \mathrm{m}$. Sections were stained with haemalum-eosin (Burck, 1981).

For enzyme-histochemical studies tissues were quickly frozen with $\mathrm{CO}_{2}$. Sections of $10 \mu \mathrm{m}$ thickness were cut with a cryostat microtome and stored at $-40^{\circ} \mathrm{C}$. Demonstration of $3 \alpha$ - and $3 \beta$-hydroxysteroid dehydrogenase ( $3 \alpha \mathrm{HSD}$ 
and $3 \beta \mathrm{HSD}$ ) was carried out according to the method of Van Den Hurk (1973), with etiocholanolone and epiandrosterone, respectively, as substrate and at an incubation temperature of $30^{\circ} \mathrm{C}$. Demonstration of uridine diphosphoglucose dehydrogenase (UDPGD) was based on the method of Jacobsen and Jørgensen (1973) modified by Van Den Hurk et al. (1987b). Control sections were incubated in a medium without substrate or NAD. Alternate sections were stained with haemalum-eosin for more detailed morphological information.

\section{Quantification of enzyme reactions and size of lumen}

By means of a scanning stage, random fields were selected in non-serial sections and examined with an IBAS-2-image analysis system (Kontron, München). Microscopical images were scanned with a videocamera equipped with a Plumbicantube. They were digitalized and stored in one of the image memories (resolution 512-512 pixels). The original image was corrected for shading by a similar input of an image of the slide without tissue section.

The objects to be measured were selected by interactive setting of grey value discrimination levels. If necessary, image corrections were carried out by means of interactive cursor actions. The system was calibrated for geometrical and densiometrical dimensions. For the latter, the black level and the white level of the background were fed into the system.

To determine the total enzyme activity the Integrated Optical Density (IOD) was used as parameter; the cell volume was estimated by measuring the area of the enzyme reactive tissue and the Average Optical Density (AOD), i.e. the IOD/area of reactive tissue, served as parameter for the intensity of the enzyme reaction.

$3 \alpha \mathrm{HSD}$ and $3 \beta \mathrm{HSD}$ reactions were measured using a narrow-band interference filter $(\lambda \max =580 \mathrm{~nm})$. From each animal ten randomly selected fields (objective $10 \times$; area per field $0.17 \mathrm{~mm}^{2}$ ) were analysed in two sections (distance between the sections $100 \mu \mathrm{m}$ ) of a proximal as well as a distal part of a lobe, taken from the mid-part of the seminal vesicle. In two testicular sections five fields (objective $6.3 \times$; area per field $0.25 \mathrm{~mm}^{2}$ ) were taken. Likewise, the UDPGD reaction in testes and seminal vesicles was measured in ten randomly selected fields (objective $6.3 \times$; area per field $0.25 \mathrm{~mm}^{2}$ ) using a red filter $(\lambda \max =625 \mathrm{~nm})$.

For the testis, the total enzyme activity and the cell volume were calculated per organ, assuming a specific gravity of $1 \mathrm{~g}$ testis per $\mathrm{cm}^{3}$. In seminal vesicles, the enzyme activity is not uniformly distributed throughout the lobes. Therefore, total enzyme activity and reacting cell volume were not expressed per seminal vesicle, but per $\mathrm{mm}^{3}$ interstitial and epithelial cells, to correct for changes in the size of the seminal vesicle tubules.

The size of the lumen of tubules in the testis and the seminal vesicle were determined by image analysis of haemalum-eosin-stained sections of frozen 
tissue. Images of seminal vesicle were scanned with the TV camera coupled to the microscope (objective $2.5 \times$; two fields with total area $14.79 \mathrm{~mm}^{2}$ ). For the testis, photographic negatives of fluorescence microscopical pictures were taken, since the interstitial tissue shows a strong fluorescence using epi-illumination with a HBO 50 mercury lamp and the microscope equipped with excitation filters LP $455+$ KP 490 , beam splitter FT 510 and LP 528 as barrier filter. The size of the image field was $8.08 \mathrm{~mm}^{2}$. The high contrast in grey level permitted a simple selection of the tubules of the image by grey level discrimination. In addition, the number of seminiferous tubules in the image was counted and the mean area per tubule was calculated.

\section{Gonadotropin (GTH) measurement}

The gonadotropin content in the blood plasma was measured using a homologous radioimmunoassay for catfish GTH according to the method of Goos et al. (1986). The most important characteristics of this assay are its accuracy of $4-8 \%$ and its range of $0.4-6.3 \mathrm{ng} \mathrm{GTH} / \mathrm{ml}$ plasma for $100-\mu \mathrm{l}$ samples. Consequently, some samples had to be diluted with $0.05 \mathrm{M}$ veronal buffer, $\mathrm{pH} 8.6$, supplemented with $0.2 \% \mathrm{BSA}$ and $0.1 \% \mathrm{Na}$-azide.

\section{Statistical analysis}

The means of individual values are given with the standard error of the mean (SEM). Data were analyzed with Bartlett's test of homogeneity of variances. When variances were heterogeneous, a logarithmic transformation was performed. Differences between groups were analyzed by a one-way analysis of variance (Sokal and Rohlf, 1969).

\section{RESULTS}

\section{Seminal vesicle}

In spawning males, the mean SVSI value was lower than in prespawning fish (Table 1). The structure of the seminal vesicle of catfish taken from their natural habitats corresponds to that previously described for laboratory-reared African catfish (Van Den Hurk et al., 1987a), i.e. it is built up of lobes containing numerous branching tubules filled with secretion product and sperm cells. The tubules are separated from each other by interstitial tissue and lined by simple epithelium. In the distal part of the lobes, the epithelial cells mainly have a flat appearance. In the proximal region, the cells are cubical or cylindrical. The size of the tubules in the distal region of the seminal vesicle lobes was reduced in spawning fish compared to prespawning fish (Fig. 1). In the proximal region no differences were observed. 
TABLE 1

Plasma gonadotropin level (GTH), gonadosomatic index (GSI) and seminal vesicle somatic index (SVSI) of prespawning and spawning African catfish (Values are means $\pm \mathrm{SEM}$ )

\begin{tabular}{lll}
\hline & Prespawning & Spawning \\
\hline $\begin{array}{ll}\text { Male fish } \\
\quad \text { Number of fish }\end{array}$ & 9 & 9 \\
GSI & $0.6 \pm 0.1$ & $1.0 \pm 0.1^{* *}$ \\
SVSI & $0.9 \pm 0.1$ & $0.6 \pm 0.1^{*}$ \\
GTH & $0.5 \pm 0.1$ & $2.8 \pm 0.8^{* * *}$ \\
Female fish & & \\
Non-ovulated & & \\
$\quad$ Number of fish & 7 & 2 \\
$\quad$ GTH & $2.8 \pm 1.1$ & $1.9 ; 3.7$ \\
Ovulated & & \\
$\quad$ Number of fish & 0 & 6 \\
$\quad$ GTH & - & $29.7 \pm 4.2^{* * *}$ \\
\hline
\end{tabular}

Data of spawning males were compared with prespawning male fish. Ovulated females were compared with unovulated females $\left({ }^{*} P<0.05 ;{ }^{* *} P<0.01 ;{ }^{* * *} P<0.005\right)$.

The steroid dehydrogenases $3 \alpha \mathrm{HSD}$ and $3 \beta \mathrm{HSD}$ were demonstrated only in interstitial cells. UDPGD was localized in both interstitial cells and the epithelium lining the seminal vesicle tubules. In interstitial cells, total activity of all three enzymes was markedly stronger in spawning fish in both the proximal and the distal regions of the seminal vesicle lobes (Figs. $2 \mathrm{~A}$ and $3 \mathrm{~A}$ ). The $3 \alpha \mathrm{HSD}$ and $3 \beta \mathrm{HSD}$ reacting cell volume was larger in spawning male fish, both in the proximal (Fig. 2C) and the distal (Fig. 3C) parts of seminal vesicle lobes. In both regions the $3 \alpha \mathrm{HSD}$ reaction intensity was stronger in spawning

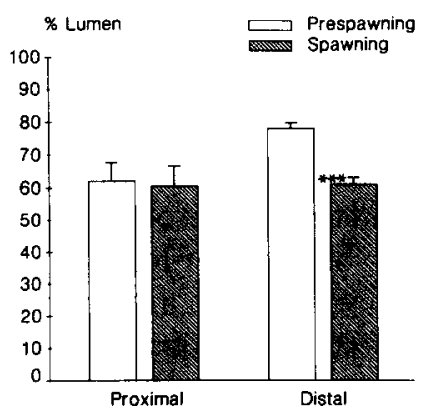

Fig. 1. Relative volume of the lumen of tubules in distal and proximal parts of seminal vesicles from prespawning $(n=9)$ and spawning $(n=9)$ male African catfish. Values are means \pm SEM. Data of spawning fish were compared with those of prespawning fish $\left({ }^{* * *} P<0.005\right)$. 

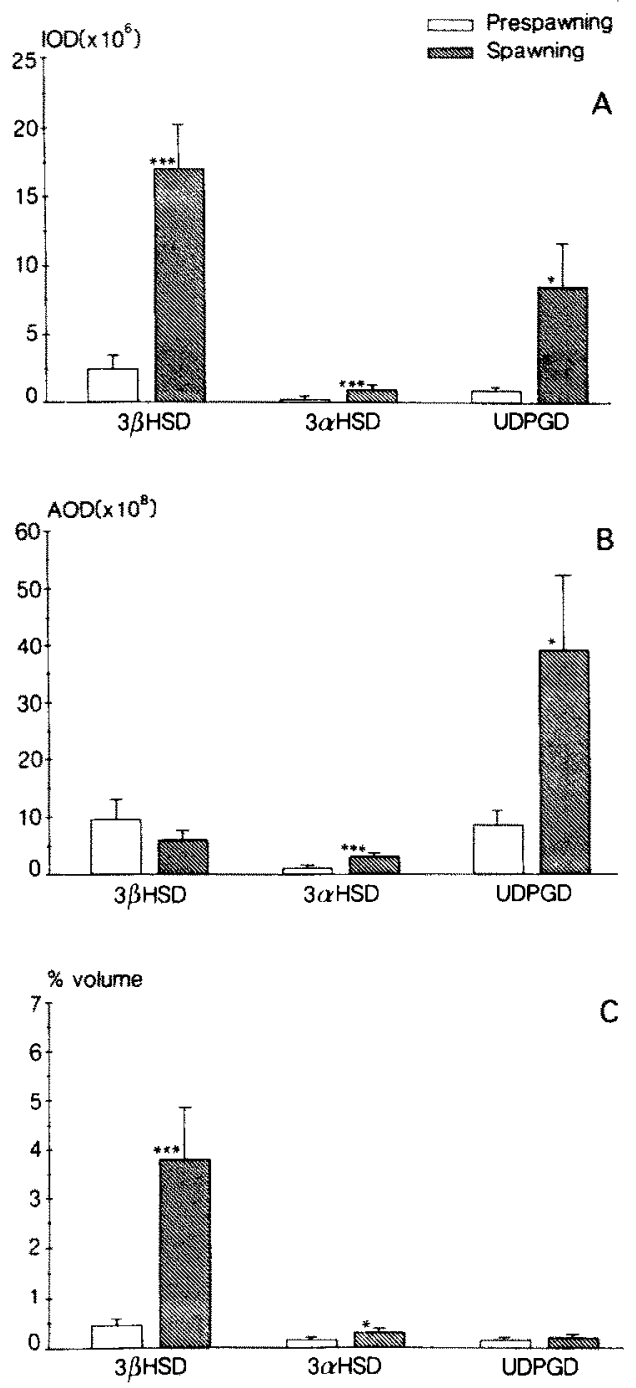

Fig. 2. $3 \beta$ HSD, $3 \alpha \mathrm{HSD}$ and UDPGD reactions in the interstitial cells of the proximal part of seminal vesicle lobes from prespawning $(n=9)$ and spawning $(n=9)$ male African catfish.

A, Total enzyme activity as expressed in integrated optical density (IOD) per $\mathrm{mm}^{3}$ interstitial and epithelial cells.

$\mathrm{B}$, Reaction intensity as expressed in average optical density ( $A O D$ ) per $\mathrm{mm}^{3}$ reactive cells. C, Reactive cell volume per $\mathrm{mm}^{3}$ interstitial and epithelial cells.

Values are means \pm SEM. Data of spawning fish were compared with those of prespawning fish $\left({ }^{*} P<0.05,{ }^{* * *} P<0.005\right)$.

fish (Fig. $2 \mathrm{~B}$ and $3 \mathrm{~B}$ ). The $3 \beta \mathrm{HSD}$ intensity in these fish was stronger only in the distal region of seminal vesicle lobes (Fig. $3 B$ ). The UDPGD reacting cell volume in the interstitial tissue showed no significant differences (Fig. $2 \mathrm{C}$ and 

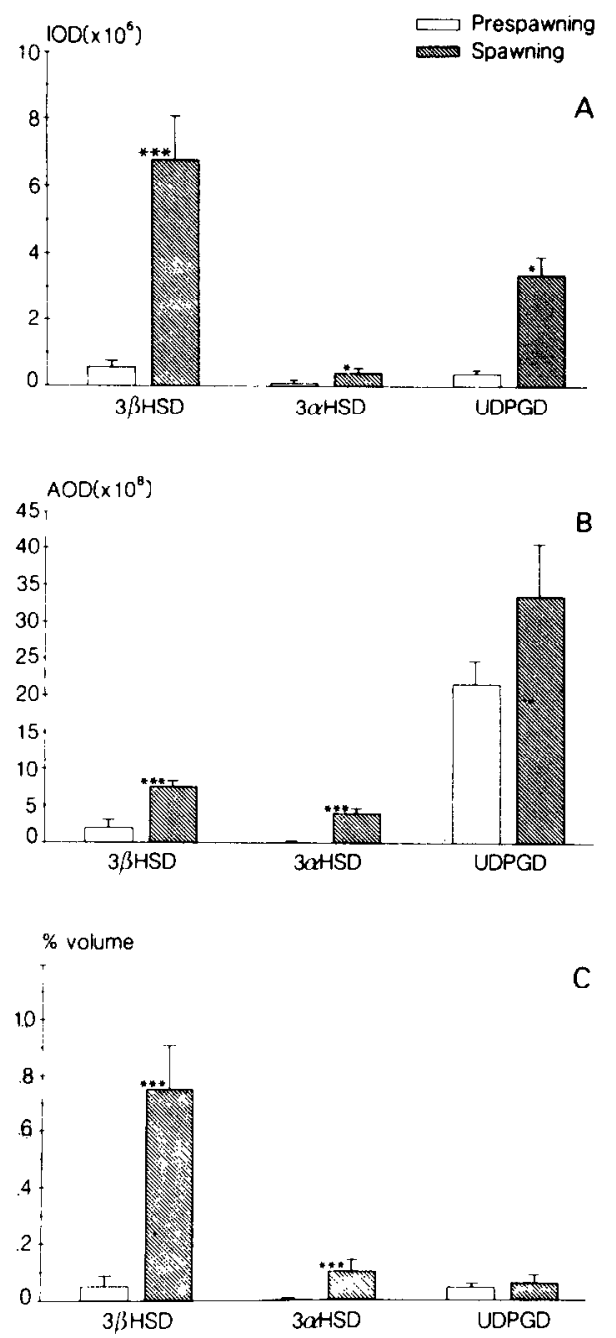

Fig. 3. 3 $\beta$ HSD, $3 \beta$ HSD and UDPGD reactions in the interstitial cells of the distal part of seminal vesicle lobes. For explanation see Fig. 2.

$3 \mathrm{C})$. The intensity of the UDPGD reaction was markedly stronger in the proximal region of seminal vesicle lobes of spawning fish (Fig. 2B). In the distal region, only a slight and not significant increase was observed (Fig. 3B). No obvious differences were found between spawning and prespawning fish with respect to total UDPGD activity, UDPGD intensity and UDPGD reacting cell volume of the epithelium of seminal vesicle tubules (Fig. 4A, B, C).

Testis

In spawning males, the mean GSI value was higher than in prespawning catfish (Table 1). Histological examination showed that the testis contained 

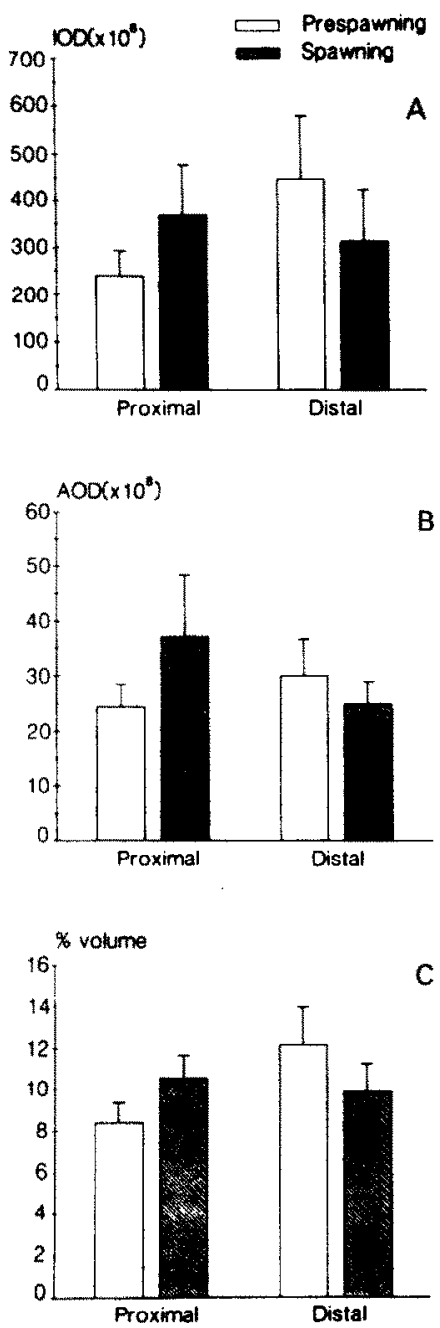

Fig. 4. UDPGD reaction in epithelial cells of the distal and proximal parts of the seminal vesicle lobes from prespawning $(n=9)$ and spawning $(n=9)$ male African catfish. For explanation see Fig. 2.

seminiferous tubules filled with spermatids and sperm cells (Fig. 5A, B). These tubules were enlarged in spawning catfish (Fig. 5B). The percentage seminiferous tubule lumen had increased slightly and the mean area per tubule was 2.5 times larger (Fig. 6).

In the testes, $3 \alpha \mathrm{HSD}, 3 \beta \mathrm{HSD}$ and UDPGD were localized in interstitial cells only. In testes of spawning catfish the total $3 \beta$ HSD activity was stronger and the UDPGD activity weaker than in prespawning fish, but the total $3 \alpha H S D$ activity did not differ (Fig. 7A). The $3 \alpha \mathrm{HSD}$ reacting cell volume was not 

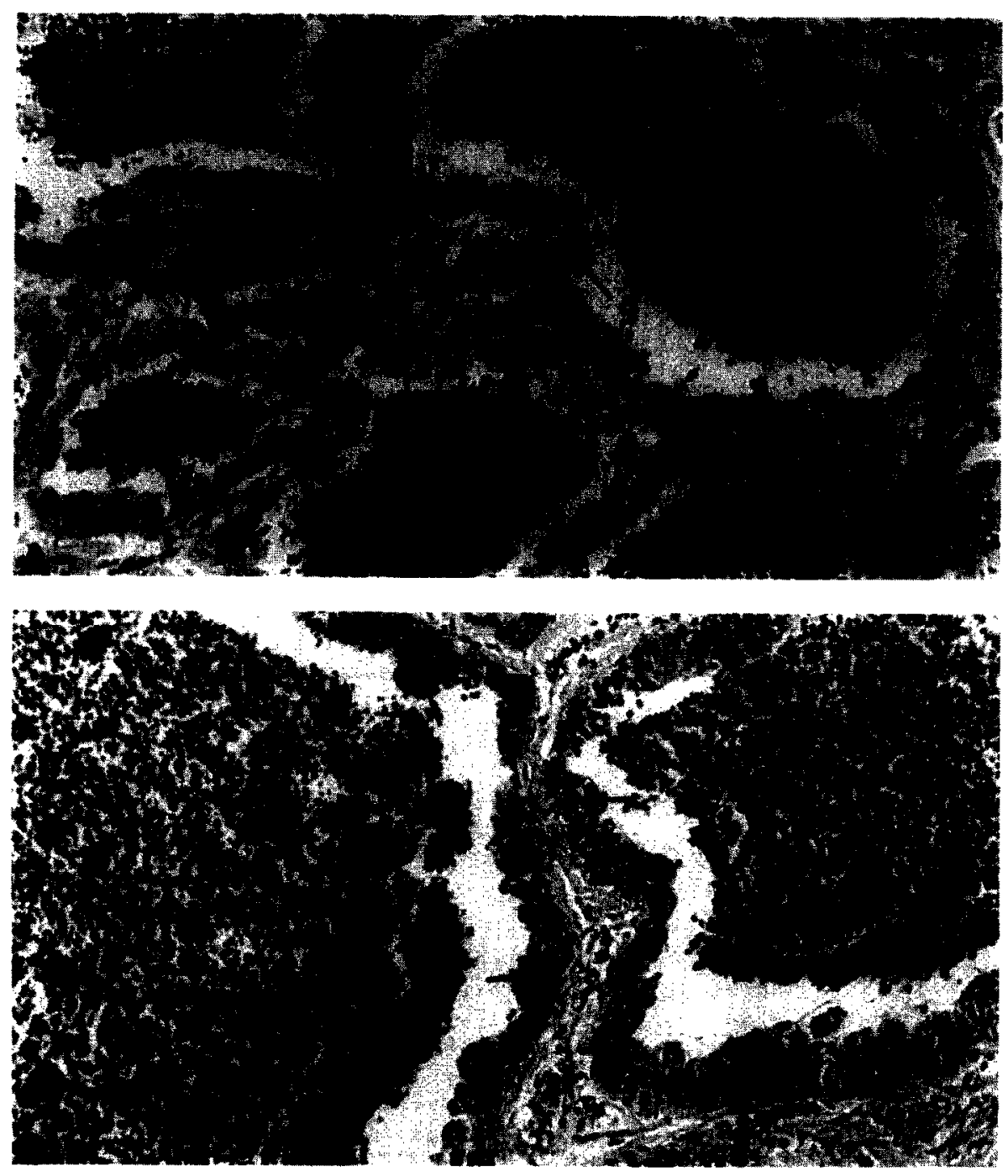

Fig. 5. Part of a cross section of a testis from a prespawning (A) and a spawning (B) catfish. The seminiferous tubules are lined by spermatogenic cysts (arrows); their lumen is filled with spermatids (ST) and sperm cells (SP) $(\times 240)$.

significantly different. The UDPGD reaction intensity was reduced in spawning males as compared with prespawning fish (Fig. 7B). However, no difference in $3 \alpha \mathrm{HSD}$ and $3 \beta \mathrm{HSD}$ intensity was observed. Compared to prespawning fish, testes of spawning animals showed a larger $3 \beta \mathrm{HSD}$ and a smaller UDPGD reacting cell volume (Fig. $7 \mathrm{C}$ ). 


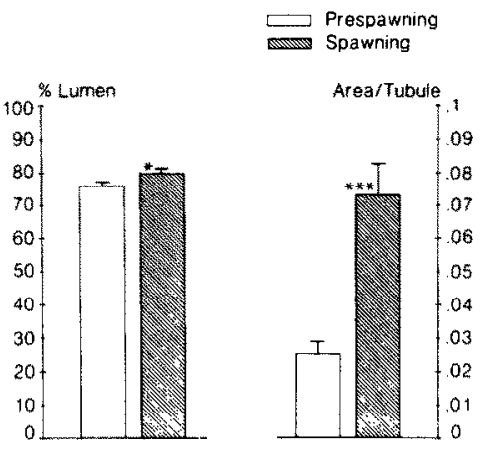

Fig. 6. Relative volume of the lumen of tubules and mean area per tubule in testes from prespawning $(n=9)$ and spawning $(n=9)$ male African catfish. Values are means \pm SEM. Data of spawning fish were compared with those of prespawning fish $\left({ }^{*} P<0.05,{ }^{* * *} P<0.005\right)$.

\section{Ovarian development and plasma GTH levels}

In the spawning group, six out of eight female fish had ovulated (Table 1). The other two and all prespawning fish had completed vitellogenesis, but did not show final maturation of oocytes and ovulation. In the latter groups of fish the mean plasma GTH level was low as compared with ovulated females (Table 1). Plasma GTH level in males was extremely low. Nevertheless, a significant elevation of this level was manifest in spawning fish.

\section{DISCUSSION}

The mean SVSI of male spawning catfish was distinctly lower than in prespawning fish. This was probably due to a release of fluid from the seminal vesicle tubules, since their size was reduced in the distal area of the lobes. Sundararaj et al. (1971) observed an extrusion of seminal vesicle secretion during spermiation in the Indian catfish, Heteropneustes fossilis, after injection with salmon gonadotropin. In African catfish the release of seminal fluid may also be controlled by GTH. At any rate, the plasma GTH levels had increased in spawning males. The seminal vesicle fluid from African catfish appears to be composed of acid polysaccharides, proteins and phospholipids and contains sperm cells (Van Den Hurk et al., 1987a). Gas chromatographic-mass spectrometric analysis of this fluid showed the presence of different steroid glucuronides (Schoonen, unpublished). The viscous seminal vesicle secretion not only serves as a vehicle for ejaculated sperm cells, but also promotes the fertilization capacity of sperm cells in Heteropneustes fossilis (Sundararaj and Nayyar, 1969) and Clarias gariepinus (Van Den Hurk et al., 1987a).

The enzymes $3 \alpha \mathrm{HSD}$ and $3 \beta \mathrm{HSD}$ are essential for the oxidation of $3 \alpha$-and $3 \beta$-hydroxysteroids, respectively, and are consequently present in cells that are involved in the biosynthesis or metabolism of steroids. In the male repro- 

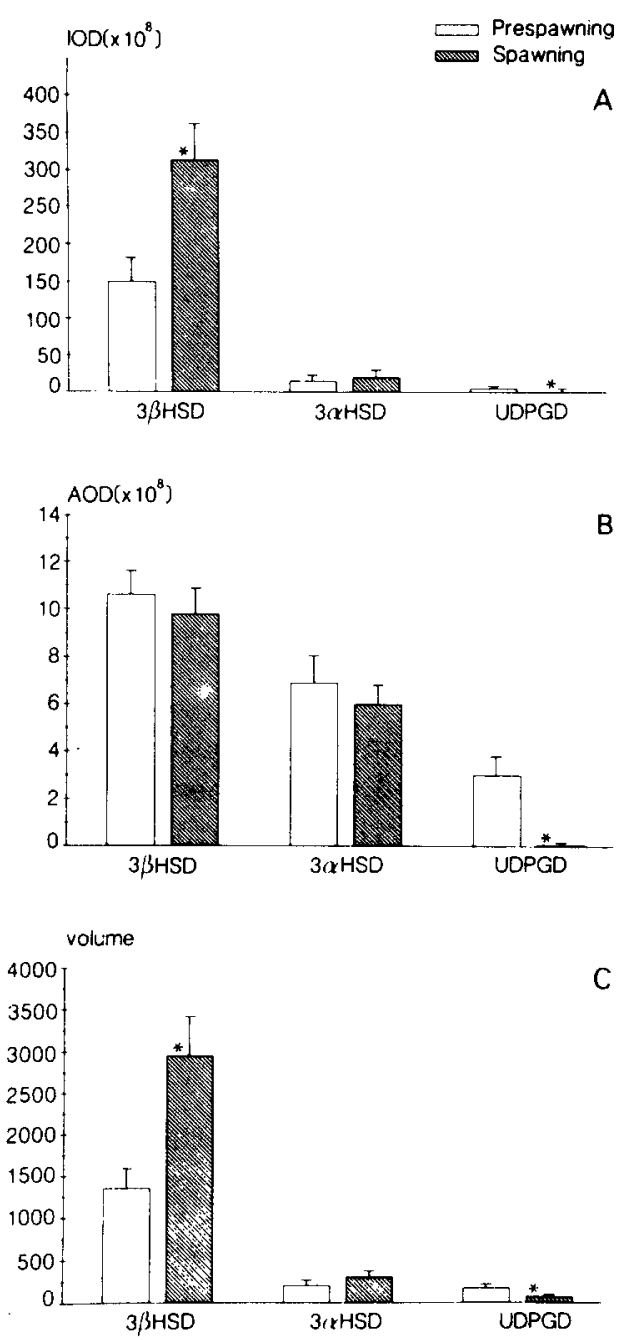

Fig. 7. $3 \beta \mathrm{HSD}, 3 \alpha \mathrm{HSD}$ and UDPGD reactions in the interstitial cells of testes from prespawning $(n=9)$ and spawning $(n=9)$ male African catfish.

A, Total enzyme activity as expressed in integrated optical density (IOD) per organ.

$B$, Reaction intensity as expressed in average optical density (AOD).

$\mathrm{C}$, Reactive cell volume per organ.

Values are means \pm SEM. Data of spawning fish were compared with those of prespawning fish $\left({ }^{*} P<0.05\right)$.

ductive system of Clarias gariepinus $3 \alpha \mathrm{HSD}$ activity is one of the determining factors for the synthesis of a variety of $5 \beta$-androstane glucuronides (Schoonen and Lambert, 1986a,b). One of these compounds, i.e. etiocholanolone glucuronide, induces attraction of female Gobius jozo, male Carassius auratus and male Poecilia reticulata (Colombo et al., 1982). UDPGD catalyzes the trans- 
formation of UDP-glucose into UDP-glucuronic acid, which is essential in the conjugation of different hydroxylated compounds, such as steroids (Dutton, 1980 ). In the present study, $3 \alpha \mathrm{HSD}, 3 \beta \mathrm{HSD}$ and UDPGD activity is demonstrated in interstitial cells distributed between the seminal vesicle tubules. In addition, UDPGD activity appeared to be present in the epithelium lining the seminal vesicle tubules. These findings correspond to previous data on captive catfish (Van Den Hurk et al., 1987a,b). It could be shown that during spawning the total activity of the three enzymes was markedly enlarged. As far as the enzyme $3 \alpha \mathrm{HSD}$ is concerned, this change could be ascribed to an increase in volume and in reaction intensity of the positive cells. In the cells showing $3 \beta \mathrm{HSD}$ activity especially, the volume of the cells had changed, and in those showing UDPGD activity only the reaction intensity was stronger. These differences may reflect differences in regulation of the activity of the three enzymes.

A higher capacity to synthesize steroids and glucuronides probably results in a stimulated production of steroid glucuronides. These water-soluble compounds are thought to be involved in biological inactivation of steroids (Kime, 1982,1986 ) or to function as sex attractants (Colombo et al., 1980, 1982; Van Den Hurk and Lambert, 1983) and ovulation inducers (Lambert et al., 1986; Van Den Hurk et al., 1987c) in fish. It is tempting to speculate from the present results that the observed increase in capacity of the seminal vesicle to produce steroids and steroid glucuronides, together with the excretion of seminal vesicle fluid during spawning are involved in the induction of ovulation and attraction of female conspecifics. Steroid glucuronides would be excellent tools for bringing scattered males and females together and for synchonization of sexual behaviour.

Like the interstitial cells in the seminal vesicle, those of the testes showed a stronger activity of the enzyme $3 \beta \mathrm{HSD}$ during spawning. This was caused by an enlargement of the volume of the reacting cells. Stimulation of testicular steroid production might be essential for the spermiation process, that has been demonstrated to be under the control of $17 \alpha, 20 \beta$-dihydroxy-4-pregnene3-one in several fish species (Ueda et al., 1983, 1985; Scott and Baynes, 1982; Baynes and Scott, 1985). The total $3 \alpha$ HSD activity, however, did not change and the UDPGD activity decreased in the interstitial cells of the testes during the spawning process. This may point to a reduction in steroid glucuronide formation in the testes of spawning catfish, and indicates that, contrary to the seminal vesicle, the testes have a minor function in the production of steroid glucuronides during spawning.

Compared to that of prespawning catfish, mean GSI had significantly increased during spawning. Histological and histometrical data showed an increase in size of the seminiferous tubules accompanied by a dilution of the sperm mass. These findings point to hydration of the seminiferous tubules, a common phenomenon during spermiation in male teleosts (Clemens and Grant, 
1965; Billard et al., 1982). The hydration response in the testis precedes the migration of sperm cells into the vas deferens (Billard et al., 1982).

The changes in steroid and steroid glucuronide formation in testis and seminal vesicles of male catfish were accompanied by an elevation in plasma gonadotropin level. This level, however, remained low in comparison with that of spawning females. Elevated, but relatively low, gonadotropin levels in males were also found during spawning in various salmonid species (Crim et al., 1975) and the carp, Cyprinus carpio (Fish Reproductive Physiology Group, 1978). Perhaps, in male African catfish, the plasma gonadotropin concentration reaches peak levels immediately before spawning and decreased during that process. This would be in accordance with findings of Van Den Hurk (1977) who observed - in male zebrafish, Brachydanio rerio - the strongest secretory activity of the gonadotropic cells during the prespawning stage.

The present data demonstrate a dramatic increase in the plasma gonadotropin level in female African catfish under natural conditions at the time of ovulation and spawning. Similarly, a periovulatory gonadotropin surge was found in other teleost species during spawning (review: Peter, 1981, Goetz, 1983; Stacey et al., 1984). This gonadotropin surge probably leads to final maturation of oocytes and ovulation, since in catfish these processes can be induced with gonadotropin preparations such as pituitary suspensions (Micha, 1975; Hogendoorn and Visman, 1980; Richter and Van Den Hurk, 1982) and HCG (Eding et al., 1982). In addition, a combined treatment of catfish with pimozide and LH-RH analogue evokes a rise in the endogenous plasma gonadotropin concentration and subsequently leads to ovulation (De Leeuw et al., 1985a,b).

Ovulation and spontaneous reproduction do not take place in culture tanks under fish farm or laboratory conditions. Inhibition of spontaneous spawning is probably due to a failure in female catfish of a rise in hypophysial gonadotropic output, caused by an insufficient release of $\mathrm{GnRH}$ (Peute et al., 1984). Therefore, plasma gonadotropic values in captive fish remain low. This hypothesis is in agreement with the results of Van Der Waal (1974), showing that spawning behaviour can be achieved by injection of a homologous pituitary suspension. Recently, Resink et al. (1987) were able to induce spawning in Clarias gariepinus, after stimulation of the endogenous gonadotropic release with pimozide and LH-RH analogue.

The present field observations regarding spawning behaviour of Clarias gariepinus in the Hula Reserve showed a positive correlation between the onset of spawning and the inflow of fresh water. Similar observations, confirming the coincidence of rainfall or inflow of water and spawning of African catfish under natural conditions, have been described previously (review: Bruton, 1979). Under semi-natural pond conditions spawning of African catfish could also be initiated by raising the water level (Micha, 1975). The specific external factors leading to the initiation of spawning are unknown. Changes in physio- 
chemical properties of the water or fresh flooding of vegetation may be responsible. In this respect, the involvement of petrichor, a substance originating from dry soil that contacts water, was suggested (Van Der Waal, 1974; Bruton, 1979). Stacey et al. (1979) showed the importance of aquatic vegetation as a stimulus for ovulation in the goldfish. Dilution of metabolic wastes by inflow of water might also induce ovulation, as has been suggested by Chen and Martinich (1975) for the zebrafish, Brachydanio rerio. In their study the presence of male conspecifics was also shown to be a prerequisite for ovulation in female zebrafish. Recently, Lambert et al. (1986) and Van Den Hurk et al. (1987c) pointed to the importance of testicular steroid glucuronides as pheromonal ovulation inducers in zebrafish. Studies on a possible pheromonal role of steroid glucuronides as ovulation inducers in African catfish are in progress.

\section{ACKNOWLEDGEMENTS}

The authors wish to thank Prof.Dr. E.A. Huisman, Prof.Dr. P.G.W.J. van Oordt and Prof.Dr. M.P. Schreibman for critically reviewing the manuscript, Ms. M. van Hattum and Ms. R. van Gelderen for typing the manuscript, the Image Processing and Design Department of the Subfaculty of Biology for making the drawings and Dr. M. Gophen, Director of the Kinneret Limnological Laboratory, at Tabgha, Israel, for his hospitality.

These investigations were partly supported by the Netherlands Foundation for Technical Research (STW), future Technical Science Branch/Division of the Netherlands Organization for the Advancement of Pure Research (ZWO), and partly by Funds of the Dutch-Israeli Clarias Project, granted to Prof.Dr. P.G.W.J. van Oordt by the Dutch Ministry of Development Cooperation.

\section{REFERENCES}

Baynes, S.M. and Scott, A.P., 1985. Seasonal variations in parameters of milt production and in plasma concentration of sex steroids of male rainbow trout (Salmo garidneri). Gen. Comp. Endocrinol., 57: 150-160.

Billard, R., Fostier, A., Weil, C. and Breton, B., 1982. The endocrine control of spermatogenesis in teleost fish. Can. J. Fish. Aquat. Sci., 39:65-79.

Bruton, M.N., 1979. The breeding biology and early development of Clarias gariepinus (Pisces: Claridae) in Lake Sibaya, South Africa, with a review of breeding in species of the subgenus Clarias (Clarias). Trans. Zool. Soc. London, 35: 1-45.

Burck, H.C., 1981. Histologische Technik-Leitfaden für die Herstellung mikroskopische Präparate in Unterricht und Praxis. Thieme, Stuttgart, New York, NY, 205 pp.

Chen, L.C. and Martinich, R.L., 1975. Pheromonal stimulation and metabolite inhibition of ovulation in the zebrafish, Brachydanio rerio. Fish Bull., 73: 889-894.

Clemens, H.P. and Grant, F.B., 1965. The seminal thinning response of carp (Cyprinus carpio) and rainbow trout (Salmo gairdneri) after injections of pituitary extracts. Copeia, 2: 174-177. 
Colombo, L., Marconato, A., Colombo Belvédère, P. and Friso, C., 1980. Endocrinology of teleost reproduction: a testicular steroid pheromone in the black goby, Gobius jozo L. Boll. Zool, 47 ; 355-364.

Colombo, L., Colombo Belvédère, P., Marconato, A. and Bentivegna, F., 1982. Pheromones in teleost fish. In: C.J.J. Richter and H.J.Th. Goos (Editors), Proc. Int. Symp. Reproductive Physiology of Fish, Wageningen, The Netherlands, 2-6 August 1982. PUDOC, Wageningen, pp. 84-94.

Crim, L.W., Watts, E.G. and Donaldson, E.M., 1975. The plasma gonadotropin profile during sexual maturation in a variety of salmonid fishes. Gen. Comp. Endocrinol., 27: 62-70.

De Leeuw, R., Goos, H.J.Th., Richter, C.J.J. and Eding, E.H., 1985a. Pimozide-LHRHa-induced breeding of the African catfish, Clarias gariepinus (Burchell). Aquaculture, 44: 295-302.

De Leeuw, R., Resink, J.W., Rooyakkers, E.J.M. and Goos, H.J.Th., 1985b. Pimozide modulates the luteinizing hormone-releasing hormone effect on gonadotropin release in the African catfish, Clarias lazera. Gen. Comp. Endocrinol., 58: 120-127.

Dutton, G.J., 1980. Glucuronidation of Drugs and other Compounds. CRC Press, Boca Raton, FL, $286 \mathrm{pp}$.

Eding, E.H., Janssen, J.A.L., Klein Staarman, G.H.L. and Richter, C.J.J., 1982. Effects of Human Chorionic Gonadotropin (HCG) on maturation and ovulation of oocytes in the catfish Clarias lazera (C, \& V.). In: C.J.J. Richter and H.J.Th. Goos (Editors), Proc. Int. Symp. Reproductive Physiology of Fish, Wageningen, The Netherlands, 2-6 August 1982. PUDOC, Wageningen, pp. 195.

Fish Reproductive Physiology Group, 1978. Radioimmunoassay on serum gonadotropin of carp (Cyprinus carpio L.). Acta Biochim. Biophys. Sin., 10: 399-407.

Goetz, F.W., 1983. Hormonal control of oocyte maturation and ovulation in fishes. In: W.S. Hoar, D.J. Randall and E.M. Donaldson (Editors), Fish Physiology, Vol. IX, Reproduction. Academic Press, New York, NY and London, pp. 117-170.

Goos, H.J.Th., De Leeuw, R., Burzawa-Gérard, E., Terlou, M. and Richter, C.J.J., 1986. Purification of gonadotropic hormone from the pituitary of the African catfish, Clarias gariepinus (Burchell) and the development of a homologous radioimmunoassay. Gen. Comp. Endocrinol., 62: $162-170$.

Hogendoorn, H. and Vismans, M.M., 1980. Controlled propagation of the African catfish, Clarias lazera (C. \& V.). II. Artificial reproduction. Aquaculture, 21: 39-53.

Jacobsen, W.O. and Jørgensen, F., 1973. Further enzyme-histochemical observations on the segmentation of the proximal tubules in the kidney of the male rat. Histochemistry, 34: 11-32.

Kime, D.E., 1982. The control of gonadal androgen biosynthesis in fish. In: C.J.J. Richter and H.J.Th. Good (Editors), Proc. Int. Symp. Reproductive Physiology of Fish, Wageningen, The Netherlands, 2-6 August 1982. PUDOC, Wageningen, pp. 95-98.

Kime, D.E., 1986. Maturational and temperature effects on steroid hormone production by testes of the carp, Cyprinus carpio. Aquaculture, 54: 49-55.

Lambert, J.G.D., Van Den Hurk, T., Schoonen, W.G.E.J., Resink and J.W. and Van Oordt, P.G.W.J., 1986. Gonadal steroidogenesis and the possible role of steroid glucuronides as sex pheromones in two species of teleosts. Fish Physiol. Biochem., 2(1-4): 101-107.

Liley, N.R., 1982. Chemical communication in fish. Can. J. Fish. Aquat. Sci., 39: 22-35.

Liley, N.R. and Stacey, N.E., 1983. Hormones, phoromones and reproductive behavior. In: W.S. Hoar, D.J. Randall and E.M. Donaldson (Editors), Fish Physiology, Vol. IX, Reproduction. Academic Press, New York, NY and London, pp. 1-63.

Micha, J.C., 1973. Etude des populations piscicoles de l'Ubangui et tentative de sélection et d'adaptation de quelques espèces à l'étang de pisciculture. C.T.F.T., Paris, 110 pp.

Micha, J.C., 1975. Synthèse des essais de reproduction d'alevinage et de production chez un silure Africain: Clarias lazera. Symp. FAO/CPCA sur l'Aquiculture en Afrique. CIFA/75/SE5, 23 pp. 
Peter, R.E., 1981. Gonadotropin secretion during reproductive cycles in teleosts: influence of environmental factors. Gen. Comp. Endocrinol., 45: 294-305.

Peute, J., De Leeuw, R., Goos, H.J.Th. and Van Oordt, P.G.W.J., 1984. Ultrastructure and immunolabeling of gonadotrops and thyrotrops in the pituitary of the African catfish, Clarias lazera. Cell Tissue Res., 238: 95-103.

Resink, J.W., Van Den Hurk, R., Groeninx van Zoelen, R.F.O. and Huisman, E.A., 1987. The seminal vesicle as source of sex attracting substances in the African catfish (Clarias gariepinus). Aquaculture, 63: 115-127.

Richter, C.J.J., 1976. The African catfish, Clarias lazera (C. \& V.), a new possibility for fish culture in tropical regions? In: E.A. Huisman (Editor), Aspects of Fish Culture and Fish Breeding. Miscellaneous Papers 13, Landbouwhogeschool Wageningen, The'Netherlands, pp. 51-71.

Richter, C.J.J. and Van Den Hurk, R., 1982. Effects of 11-desoxycorticosterone-acetate and carp pituitary suspension on follicle maturation in the ovaries of the African catfish. Clarias lazera (C. \& V.). Aquaculture, 29: 53-66.

Schoonen, W.G.E.J. and Lambert, J.G.D., 1986a. Steroid metabolism in the testis of the African catfish, Clarias gariepinus (Burchell), during the spawning season, under natural conditions and kept in ponds. Gen. Comp. Endocrinol., 61: 40-52.

Schoonen, W.G.E.J. and Lambert, J.G.D., 1986b. Steroid metabolism in the seminal vesicles of the African catfish, Clarias gariepinus (Burchell) during the spawning season, under natural conditions and kept in ponds. Gen. Comp. Endocrinol., 61: 355-367.

Schoonen, W.G.E.J., Granneman, J.C.M., Lambert, J.G.D. and Van Oordt, P.G.W.J., 1987. Steroidogenesis in the testes and seminal vesicles of spawning and non-spawning African catfish, Clarias gariepinus. Aquaculture, 63: 77-88.

Scott, A.P. and Baynes, S.M., 1982. Plasma levels of sex steroids in relation to ovulation and spermiation in rainbow trout (Salmo gairdneri). In: C.J.J. Richter and H.J.Th. Goos (Editors), Proc. Int. Symp. Reproductive Physiology of Fish, Wageningen, The Netherlands, 2-6 August 1982. PUDOC, Wageningen, pp. 103-106.

Sokal, R.R. and Rohlf, F.J., 1969. Biometry. The Principles and Practice of Statistics in Biological Research. Freeman, San Francisco, CA, 776 pp.

Stacey, N.E., Cook, A.F. and Peter, R.E., 1979. Spontaneous and gonadotropin-induced ovulation in the goldfish, Carassius auratus L.: effects of external factors. J. Fish Biol., 15: 349-361.

Stacey, N.E., MacKenzie, D.S., Marchant, T.A., Kyle, A.L. and Peter, R.E., 1984. Endocrine changes during natural spawning in the white sucker, Catostomus commersoni. I. Gonadotropin, growth hormone and thyroid hormones. Gen. Comp. Endocrinol., 56: 333-348.

Stacey, N.E., Kyle, A.L. and Liley, N.R., 1986. Fish reproductive pheromones. In: D. Duvall, D. Muller-Schwarze and R.M. Silverstein (Editors), Chemical Signals in Vertebrates, Vol. IV, Fourth International Conference on Chemical Signals in Vertebrates, Laramie, WY, 27-30 July 1985. Plenum Press, New York, in press.

Sundararaj, B.I. and Nayyar, S.K., 1969. Effect of extirpation of "seminal vesicles" on the reproductive performance of the male catfish, Heteropneustes fossilis (Bloch). Physiol. Zool., 42: 429-437.

Sundararaj, B.I. and Nayyar, S.K., Annand, T.C. and Donaldson, E.M., 1971. Effects of salmon pituitary gonadotropin, ovine luteinizing hormone and testosterone on the testes and seminal vesicles of hypophysectomized catfish, Heteropneustes fossilis (Bloch). Gen. Comp. Endocrinol., 17: 73-82.

Ueda, H., Young, G., Crim, L.W., Kambegawa, A. and Hagahama, Y., 1983. 17 $\alpha, 20 \beta$-Dihydroxy4-pregnen-3-one: plasma levels during sexual maturation and in vitro production by the testes of amago salmon (Oncorhynchus rhodurus) and rainbow trout (Salmo gairdneri). Gen. Comp. Endocrinol., 51: 106-112.

Ueda, H., Kambegawa, A. and Nagahama, Y., 1985. Involvement of gonadotrophin and steroid 
hormones in spermiation in the amago salmon, Oncorhynchus rhodurus, and goldfish, Carassius auratus. Gen. Comp. Endocrinol, 59: 24-30.

Van Den Hurk, R., 1973. The localization of steroidogenesis in the testes of oviparous and viviparous teleosts. Proc. K. Ned. Akad. Wet. Ser. C, 76: 270-279.

Van Den Hurk, R., 1977. Arguments for a possible endocrine control of the reproductive behaviour of male zebrafish (Brachydanio rerio). J. Endocrinol., 72: 63.

Van Den Hurk, R. and Lambert, J.G.D., 1983. Ovarian steroid glucuronides function as sex pheromones for male zebrafish. Brachydanio rerio. Can. J. Zool., 61: 2381-2387.

Van Den Hurk, R., Resink, J.W. and Peute, J., 1987a. The seminal vesicle of the African catfish, Clarias gariepinus. A histological, histochemical, enzyme-histochemical, ultrastructural and physiological study. Cell Tissue Res., 247: 573-582.

Van Den Hurk, R., Resink, J.W. and Voorthuis, P., 1987b. An enzyme-histochemical study concerning the localization of steroid glucuronide production in the reproductive organs of African catfish, Clarias gariepinus. Aquaculture, 63: 89-96.

Van Den Hurk, R., Van Zoelen, G.A., Schoonen, W.G.E.J., Resink, J.W. and Lambert, J.G.D., 1987c. Do testicular steroid conjugates of zebrafish, Brachydanio rerio, evoke ovulation in female conspecifics? Gen. Comp. Endocrinol., 66: 18-19.

Van Der Waal, B.C.W., 1974. Observations on the breeding habits of Clarias gariepinus (Burchell). J. Fish Biol., 6: 23-27. 